Sciences

Vol. 06, No. 02, pp. 122-138, June 2013

\title{
EXPERIMENTAL INVESTIGATION OF PRESSURE DISTRIBUTION ALONG MAKHOOL DAM SPILLWAY
}

\author{
Muhanad Mohammed Abbas \\ Engineering College, Diyala University \\ Muhanad_mohammed@yahoo.com \\ (Received:4/5/2011; Accepted:2/10/2012)
}

\begin{abstract}
This research is an experimental investigation on the pressure distribution along the surface of Makhool Dam spillway. The work is carried out as series of tests; these series are on the model as it is designed.

(17) Piezometers are fixed along the spillway surface and (4)discharges are performed on the model. The results indicated that the pressure distribution is reduced with the increase of the discharge and it is increasing with the decrease of the discharge, and there are two regions of negative pressure; the first at the ogee curve and the second at the end of the sloping straight line after ogee curve, so the slope of the horizontal surface of spillway can be reduced or change the ogee formula to prevent the cavitations' problems.
\end{abstract}

Keywords:- hydraulic structures, pressure distribution, piezometer, overflow spillway.

\section{INTRODUCTION}

Some of the hydraulic structures problems has attracted the hydraulic engineers for along time. One of these problems is the determination of the pressures on the surface of the spillways in order to modify spillway profile design. If it is designed exactly in the shape of the lower napp of free over flow, the pressure on the spillway crest under the design head should be theoretically nil. For practical reasons, however, such as ideal profile is generally modified so that low pressure will develop under the design head.

So, the pressure on the spillways may be accurately determined analytically by a numerical method, graphically by flow-net analysis, or instrumentally by electronic analogy.More exact determination of pressure, however, will depend on model investigate and tests. 


\section{2- REVIEW AND THEORY}

In the literature, enormous information are available about the pressure determination on the spillways, this can be found in ${ }^{(1,2,3)}$. Information about the relations between the upstream head with the piezometer location and piezometer reading can be found in ${ }^{(4,5,6,7)}$.

\section{Basic Hydraulics}

With reference to a straight sloping channel of unit width and slope angle $\theta($ fig. 1$)$, the weight of the shaded water element of length $d L$ is equal to $w y \cos \theta d L$. The pressure due to this weight is $w y \cos ^{2} \theta d L$. The unit pressure is , therefore, equal to $w y \cos ^{2} \theta$, and the head is:

$$
h=y \cos 2 \theta
$$

or

$$
h=d \cos ^{2} \theta
$$

Where $d=y \cos \theta$, the depth measured perpendicularly from the water surface. It should be noted from geometry that eq. (1) does not apply strictly to varied flow, particularly when $\theta$ is very large, whereas eq.(2) still applies. equation(1) states that the pressure head at any vertical depth is equal to this depth multiplied by a correction factor $\cos ^{2} \theta$. Apparently, if the angle $\theta$ is small, this factor will not differ appreciably from unity. In fact, the correction tends to decrease the pressure head by an amount less than $1 \%$ until $\theta$ is nearly $6^{\circ}$, a slope of about 1 in 10 . Since the slope of ordinary channels is far less than 1 in 10 , the correction for slope effect can usually be safely ignored. However, when the channel slopeis large and its effect becomes appreciable, the correction should be made if accurate computation is desired. Achannel of this type,say,with a slope greater than 1in 10, is hereafter called a channel of large slope . Unless specifically mentioned, all channels described hereafter are considered to be channels of small slope, where the slope effect is negligible .

If a channel of large slope has a longitudinal vertical profile of appreciable curvature, the pressure head should be corrected for the effect of the curvature of streamlines(fig.2). In simple notation, the pressure head may be expressed as $\alpha^{\prime} y \cos ^{2} \theta$, where $\alpha^{\prime}$ is the pressure coefficient.

In channels of large slope the velocity of flow is usually high, and higher than the critical velocity. When this velocity reaches a certain magnitude, the flowing water will entrain air, producing a swell in its volume and an increase in depth. For this reason the pressure computed by Eq. (1) or (2)has been shown in several cases to be higher than the actual measured pressure obtained by model testing. If the average density of the air -water 
mixture is known, it should be used to replace the density of pure water in the computation when air entrainment is expected. The actual density of the mixture varies from the bottom to the surface of the flow. For practical purposes, however, the density may be assumed constant; this assumption of uniform air distribution in the cross section will simplify computation, with the errors on the safe side.

\section{3- EXPERIMENTAL WORK}

The experimental work is carried out at the hydraulic laboratory of the college of Engineering Al-Mustansiria University. The hydraulic model is as shown in fig. (3) and fig. (4).Altogether (4) experiments are performed by using emergency spillway, and with each experiment (17) piezometer are read.

\section{The Flume}

The laboratory flume is $(20.0 \mathrm{~m})$-working length, $(0.9 \mathrm{~m})$ width and $(0.6 \mathrm{~m})$ depth with armored plate-glass sidewalls. On the top of the sidewalls, there are rails along which instrument carriages could be moved. The flume base is made of steel plate. Water is supplied to the flume through $(0.3 \mathrm{~m})$ delivery pipe discharging into a steel inlet tank $(2.0 \mathrm{~m}$ length, $1.6 \mathrm{~m}$ width and $0.9 \mathrm{~m}$ depth). At the downstream end of the flume, an exit tank $(1.7 \mathrm{~m}$ length, $0.9 \mathrm{~m}$ width and $0.8 \mathrm{~m}$ depth), also made of steel, is provided from which the flow passes via the sump to the suction pipe of the pump.

Both inlet and outlet tanks are rigidly attached to the upstream and downstream ends of the flume, and the whole system is mounted on the steel frame supported on two cylindrical bearings at its center. For electrically controlled screw jacks with system of gears, each pair on one end of the flume is provided to enable rotation of the flume about a central bearing, thus allowing the flume slope to be adjusted as required.

A large sump tank is constructed along the side of the flume under the laboratory floor.Water is stored in this tank and pumped to the flume via an axial flow vertical pump $(100 \mathrm{~L} / \mathrm{s})$ maximum capacity, with $(22 \mathrm{~kW})$ and (1460-rpm) motor. The flow is controlled by a manually operated valve, installed on the circulation system pipe. The pump can be kept at a stable operation by means of a by-pass pipe controlled by a butterfly valve.

\section{The Hydraulic Model}

To investigate the pressure distribution on over of Makhool Dam spillway, a sectional hydraulic model with scale 1:50 of the spillway is constructed from Perspex sheets, to 
provide the visibility and which is necessary for visual observation of the flow to show the flow through the model. The dimensions of the model are scaled down prototype dimensions to a scale of 1:50 selected to suite the flume and to keep the similarity condition. This model represents one bay of the prototype.

To accommodate the model in the flume, the height of the inlet part to the model is raised to $120 \mathrm{~cm}$, by adding an additional steel tank connected to the flume inlet part. The steel tank is constructed at distance $(1.5 \mathrm{~m})$ from the existing inlet steel tank of the flume. The length of the additional tank is $(240 \mathrm{~cm})$, of width $(60 \mathrm{~cm})$ and height $(120 \mathrm{~cm})$. This tank is divided into two parts by Perspex sheet with 624 openings each $(0.2 \mathrm{~cm})$ in diameter. The length of the first part is $(1 \mathrm{~m})$ and second part is $(1.4 \mathrm{~m})$. Water is supplied to this tank via two flexible hoses, due to the limitation of the standard dimensions of the Perspex sheets.

\section{Instrumentation and Measurements}

The following measuring instruments are used throughout the experimental work.

\section{Discharge Measurement}

Discharge is measured by a rectangular uncontrolled sharp crested weir, manufactured according to (B.S.I) British standard institution part 4. The weir is manufactured from Perspex plate of $(10 \mathrm{~mm})$ thickness installed at downstream end as shown in fig.(5). The head upstream the weir is measured by using a hock type gauge with a vernire scale reading $(0.1 \mathrm{~mm})$, as shown in plate (2). To eliminate the errors in gauge reading due to flow turbulence and surface waves, a well gauge is installed at $(1.5 \mathrm{~m})$ distance from the weir connected to the flume bed. At the downstream of the weir, two flexible tubes are installed, one at end side of the weir to ensure proper aeration of the flow lower nap .

Rehbock formula is used for the calculation of the discharge or by using the rating curve shown in fig. (6);

$$
Q\left(m^{3} / s\right)=C_{e} \frac{2}{3} \sqrt{2 g} B H_{e}^{3 / 2}
$$

in which:

$$
\mathrm{Ce}=0.602+0.083 \mathrm{H}_{\mathrm{w}} / \mathrm{P}
$$

$\mathrm{He}=\mathrm{H}_{\mathrm{w}}+0.0012$

$\left(\mathrm{H}_{\mathrm{w}}, \mathrm{He}, \mathrm{P}, \mathrm{B}\right)$ in meter. 


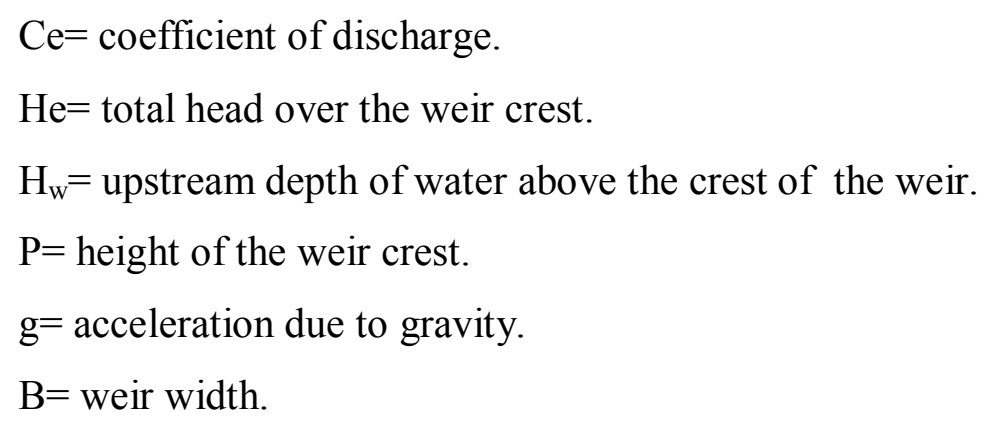

\section{Water Level Measurement}

An accurate long point gauge with a venire-scale reading to $0.1 \mathrm{~mm}$ is used for measuring water levels. This gauge is supported by an aluminum bass with Perspex pointer on a carrier mounted on two rails fixed on the top of the flume sides and could be moved in three directions. The pointer of the base moves against a metric scale fixed on the front of the carrier to show the position of the point gauge across the width of the flume and two streak pointers are screwed within the rail from the outer side of the flume to read the position of the point gauge along the flume. Due to water fluctuation in water surface, a well gauge is used at the downstream of the model connected to the side wall of the model and another is used upstream the gate.

\section{Water Temperature Measurement}

Water temperature is recorded by a thermometer. Two or three readings are recorded for each test run and the effective temperature is taken as the mean of these reads. The range of water temperature during the whole work of this study varies from $27 \mathrm{C}^{0}$ to $29 \mathrm{C}^{0}$.

\section{Pressure Measurements}

A total of (17) copper pieces each of $3 \mathrm{~cm}$ length is inserted at the center of the spillway surface, $5 \mathrm{~cm}$ a part. Flexible tubes are connected to these pieces and used to measure the pressure at those points.

\section{The Experimental Program}

The model are constructed as it designed used in this work. Altogether (4) experiments are performed by using this physical model. The variables measured (i.e.X, $\mathrm{H}_{\mathrm{u}}$, $h_{p}, H_{w}$,water temperature.), (17) piezometers are measured (4) times of spillway-cover wide range of the model which amount to (204) data points.

$\mathrm{X}=$ distance along the spillway. 
$\mathrm{Hu}=$ upstream water depth.

$\mathrm{hp}=$ piezometer head.

$\mathrm{Hw}=$ upstream water depth above weir crest.

\section{4- SIMILITUDE}

To ensure complete similarity, it is essential that both, the model and the prototype are geometrically similar.

Geometric similarity: When the shape of the model is similar to the prototype, geometric similarity is said to exist. This means that the ratio between all corresponding lengths including roughness between model and prototype is equal. This ratio $\left(\mathrm{L}_{\mathrm{r}}\right)$ is called the scale ratio.

Now, Length ratio $\left(\mathrm{L}_{\mathrm{r}}\right)=\mathrm{L}_{\mathrm{m}} / \mathrm{L}_{\mathrm{p}}$

Area ratio $=A_{m} / A_{p}=\left(L_{m} / L_{p}\right)^{2}=\left(L_{r}\right)^{2}$

Volume ratio $=\mathrm{V}_{\mathrm{m}} / \mathrm{V}_{\mathrm{p}}=\left(\mathrm{L}_{\mathrm{m}} / \mathrm{L}_{\mathrm{p}}\right)^{3}=\left(\mathrm{L}_{\mathrm{r}}\right)^{3}$

For this model $\left(\mathrm{L}_{\boldsymbol{r}}\right)$ is taken to be $(0.02)$

\section{5-DATA ANALYSISAND RESULTS}

The results concerning the pressure distribution as piezometer location (X), upstream head $\left(\mathrm{H}_{\mathrm{u}}\right)$, piezometer head $\left(\mathrm{h}_{\mathrm{p}}\right)$, which are plotted by $\left(\mathrm{X} / \mathrm{H}_{\mathrm{u}}\right)$ with $\left(\mathrm{hp} / \mathrm{H}_{\mathrm{u}}\right)$ as shown in figures (7), (8), (9) and (10) and pressure distribution with the distance as shown in fig. (11), (12), (13), and (14).

\subsection{Pressure distribution along the upper surface of the emergency spillway}

From the experimental data shown in the table (1) and figures (7) to (10) of the pressure distribution along the upper surface of the emergency spillway, it becomes clear that the pressure distribution is decrease with the increase in the discharge.

\subsection{Piezometers reading along the emergency spillway surface}

From the piezometers reading data shown in the table (2) and figures (11) to (14), it becomes clear that there are two regions of negative readings; the first at the ogee curve and the second at the end of the sloping straight line after ogee curve. These negative readings reduce with the increasing discharge. 


\section{6-CONCLUSIONS AND RECOMMENDATIONS}

1- The experimental data of the pressure distribution along the upper surface of the emergency spillway shown that these pressure distribution is reduced with the increase in the discharge and it is increase with decrease the discharge.

2- The experimental data of the piezometers reading shown that there are two regions of negative readings and These negative readings reduce with the increasing discharge .

The following is recommended are suggested for further research:

It would be interesting to continue the present study by carrying out detailed measurements for the pressure fluctuations (variation of pressure with time) using more sophisticated computerized setup including pressure transducers since the piezometers give the range values only.

\section{REFERENCES}

1. Chow, Ven T., “Open Channel Hydraulics”, Mc. Grow Hill, 1959.

2. Corps of Engineer, "Energy Dissipation and Downstream Channel Protection", Engineering Monograph, 1110-2-1602, March 1987.

3. Shou Long Yang, "Dispersive-Flow Energy Dissipater", Journal of Hydraulic Engineering, volume 120, No. 12, December 1994.

4. Jabara M.P. and Legas J., "Selection of Spillway, Plunge Pools, and Stilling Basins for Earth and Concrete Dams", The Transaction of the Eleven International Congress on Large Dams, volume 11, Madride 1973.

5. Corps of Engineer, “Energy Dissipators”, Engineering Monograph, 1110-2-1603, January 1990.

6. Henery H. Thomas, “The Engineering of Large Dams",1963.

7. Muhanad M. A.,"Experimental Investigation on the Hydraulic Performance of Combined Hydraulic Jump and Plunge Pool Stilling Basin For Makhool Dam ",Ms.c. Thesis, Department of Environmental Engineering, Al-Mustansiria University, 2002. 
EXPERIMENTAL INVESTIGATION OF PRESSURE DISTRIBUTION ALONG MAKHOOL DAM SPILLWAY

Table (1):-Pressure Distribution along Emergency Spillway Surface.

\begin{tabular}{|c|c|c|c|c|c|c|c|c|}
\hline$Q_{m}(\mathrm{~L} / \mathrm{s})$ & \multicolumn{2}{|c|}{2.708} & \multicolumn{2}{c|}{3.23} & \multicolumn{2}{c|}{3.491} & \multicolumn{2}{c|}{4.419} \\
\hline $\mathrm{Q}_{\mathrm{p}}\left(\mathrm{m}^{3} / \mathrm{s}\right)$ & \multicolumn{2}{|c|}{765.93} & \multicolumn{2}{c|}{913.58} & \multicolumn{2}{c|}{987.4} & \multicolumn{2}{c|}{1250} \\
\hline $\begin{array}{c}\text { Piezom.N } \\
\text { o. }\end{array}$ & $\mathrm{X} / \mathrm{Hu}$ & $\mathrm{hp} / \mathrm{Hu}$ & $\mathrm{X} / \mathrm{Hu}$ & $\mathrm{hp} / \mathrm{Hu}$ & $\mathrm{X} / \mathrm{Hu}$ & $\mathrm{hp} / \mathrm{Hu}$ & $\mathrm{X} / \mathrm{Hu}$ & $\mathrm{hp} / \mathrm{Hu}$ \\
\hline 1 & 0.06 & 0.99 & 0.06 & 0.98 & 0.06 & 0.98 & 0.06 & 0.98 \\
\hline 2 & 0.17 & 0.98 & 0.17 & 0.97 & 0.17 & 0.97 & 0.17 & 0.96 \\
\hline 3 & 0.28 & 0.98 & 0.28 & 0.97 & 0.28 & 0.96 & 0.28 & 0.96 \\
\hline 4 & 0.38 & 0.97 & 0.38 & 0.96 & 0.38 & 0.96 & 0.38 & 0.95 \\
\hline 5 & 0.49 & 0.97 & 0.49 & 0.96 & 0.49 & 0.95 & 0.49 & 0.95 \\
\hline 6 & 0.60 & 0.95 & 0.60 & 0.96 & 0.60 & 0.96 & 0.60 & 0.95 \\
\hline 7 & 0.70 & 0.96 & 0.70 & 0.96 & 0.70 & 0.96 & 0.70 & 0.95 \\
\hline 8 & 0.81 & 0.96 & 0.81 & 0.95 & 0.81 & 0.95 & 0.81 & 0.94 \\
\hline 9 & 0.83 & 0.96 & 0.83 & 0.94 & 0.83 & 0.94 & 0.83 & 0.92 \\
\hline 10 & 0.86 & 0.94 & 0.86 & 0.93 & 0.86 & 0.92 & 0.86 & 0.87 \\
\hline 11 & 0.89 & 0.79 & 0.89 & 0.78 & 0.89 & 0.78 & 0.89 & 0.81 \\
\hline 12 & 0.99 & 0.83 & 0.99 & 0.82 & 0.99 & 0.81 & 0.99 & 0.79 \\
\hline 13 & 1.11 & 0.70 & 1.11 & 0.69 & 1.11 & 0.68 & 1.11 & 0.68 \\
\hline 14 & 1.20 & 0.58 & 1.20 & 0.56 & 1.20 & 0.56 & 1.20 & 0.59 \\
\hline 15 & 1.29 & 0.52 & 1.29 & 0.52 & 1.29 & 0.51 & 1.29 & 0.51 \\
\hline 16 & 1.36 & 0.48 & 1.36 & 0.48 & 1.36 & 0.48 & 1.36 & 0.48 \\
\hline 17 & 1.48 & 0.51 & 1.48 & 0.44 & 1.48 & 0.51 & 1.48 & 0.44 \\
\hline
\end{tabular}


Table (2):-Measured Piezometers Reading for the Spillway (cm).

\begin{tabular}{|c|c|c|c|c|c|}
\hline \multicolumn{2}{|c|}{$\mathrm{Q}_{\mathrm{m}}(\mathrm{L} / \mathrm{s})$} & 2.708 & 3.230 & 3.491 & 4.419 \\
\hline \multirow{4}{*}{$\mathrm{H}_{\mathrm{u}}(\mathrm{cm})$} & & 62.7 & 63.3 & 64.0 & 65.4 \\
\hline \multirow{5}{*}{ Sloping } & 1 & 1.7 & 2.0 & 2.5 & 3.7 \\
\cline { 2 - 6 } & 2 & 1.17 & 1.57 & 2.07 & 3.07 \\
\cline { 2 - 6 } & 3 & 1.23 & 1.33 & 1.93 & 2.85 \\
\cline { 2 - 6 } & 4 & 1.09 & 1.19 & 1.69 & 2.49 \\
\cline { 2 - 6 } & 5 & 1.05 & 1.25 & 1.55 & 2.65 \\
\cline { 2 - 6 } & 6 & 0.92 & 1.32 & 1.82 & 2.92 \\
\cline { 2 - 6 } & 7 & 0.88 & 1.08 & 1.88 & 2.78 \\
\hline \multirow{5}{*}{ Ogee } & 8 & 0.84 & 1.04 & 1.74 & 2.41 \\
\cline { 2 - 6 } & 9 & 0.8 & 0.5 & 0.9 & 1.3 \\
\cline { 2 - 6 } & 10 & 0.5 & 0.3 & 0.6 & -0.3 \\
\hline \multirow{5}{*}{ Sloping } & 11 & -5.5 & -5.7 & -5.0 & -2.6 \\
\cline { 2 - 6 } & 12 & 0.3 & 0.5 & 0.5 & 0.8 \\
\cline { 2 - 6 } & 13 & 0.2 & 0.5 & 0.3 & 1.3 \\
\hline \multirow{3}{*}{ Ski-jump } & 14 & -1.3 & -1.7 & -1.6 & 0.9 \\
\cline { 2 - 6 } & 15 & 0 & 0 & 0.2 & 0.5 \\
\cline { 2 - 6 } & 16 & 0 & 0 & 0.5 & 1.1 \\
\hline
\end{tabular}

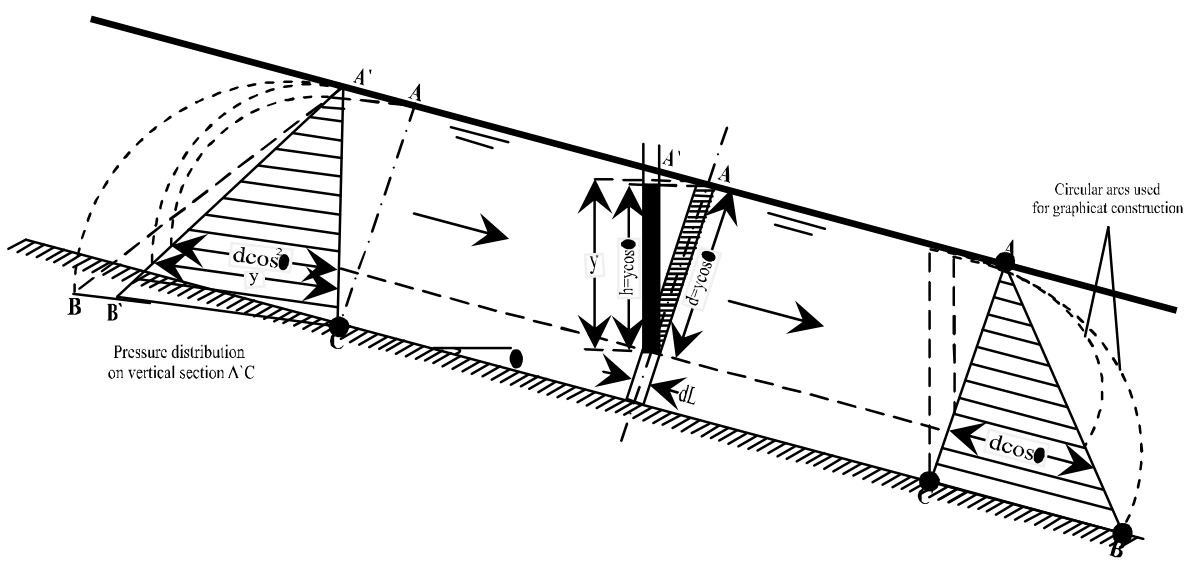

Fig.(1):- Pressure distribution in channels of large slope. 

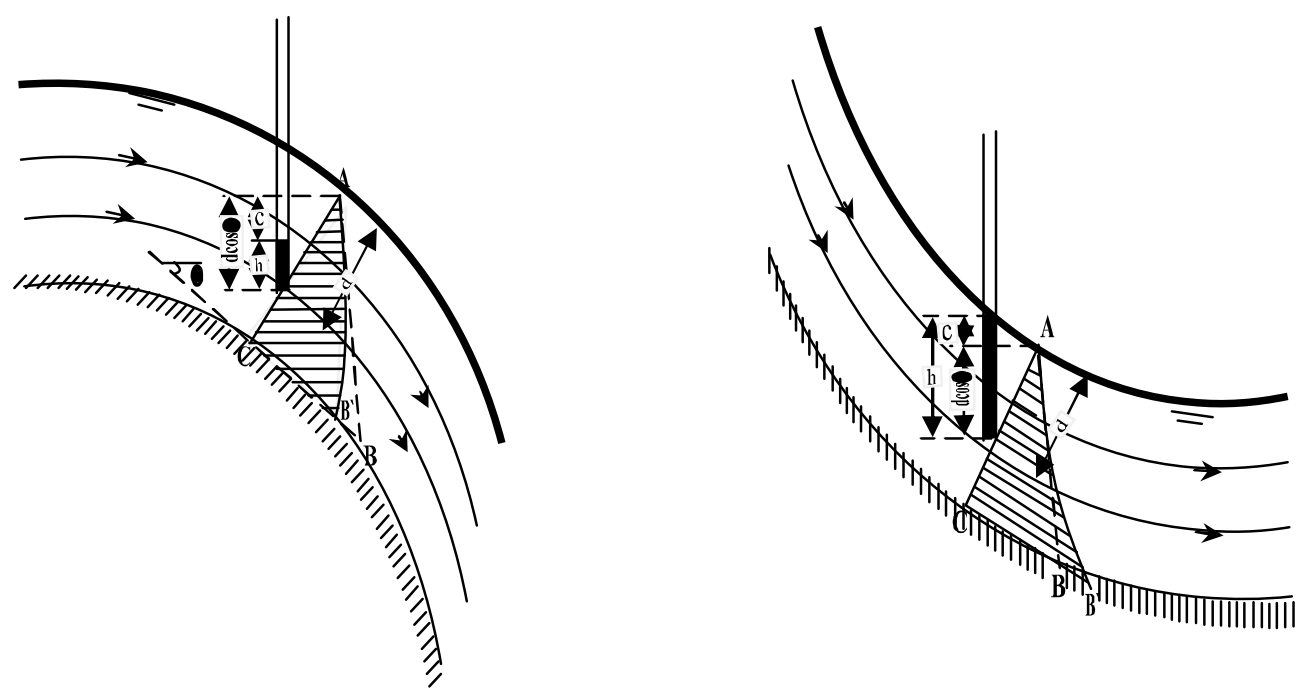

Fig.(2):- Pressure distribution in curvilinear channels of large slope.

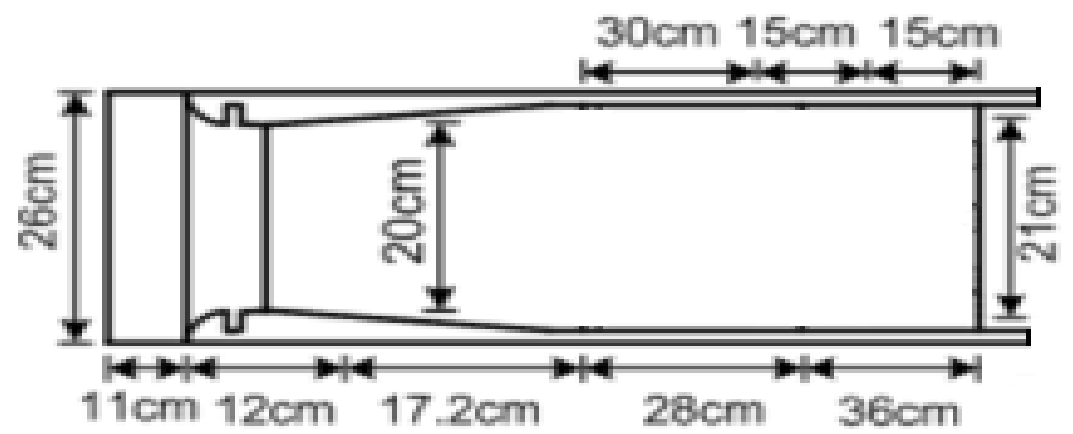

Fig. (3):- Plan view of the Hydraulic Model.

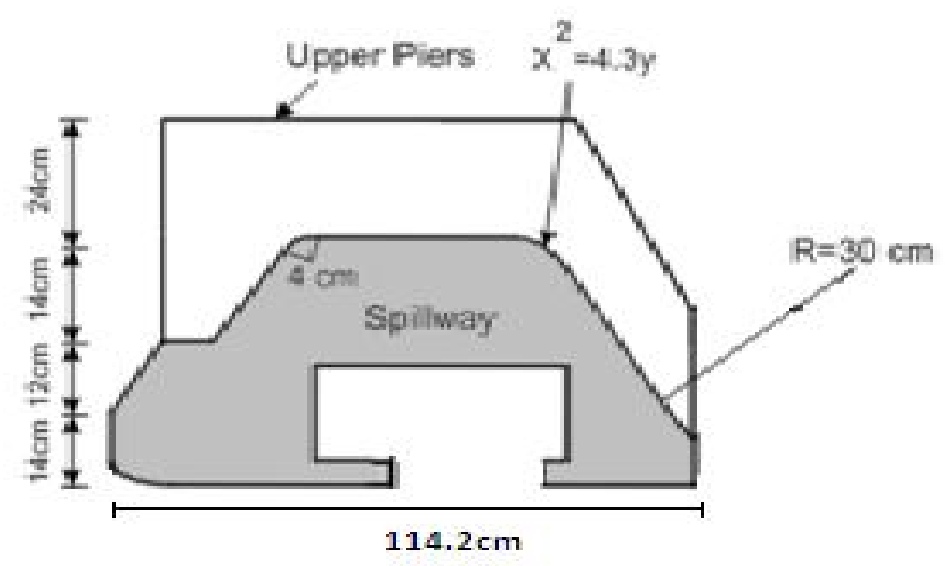

Fig.(4):- Cross Section. 

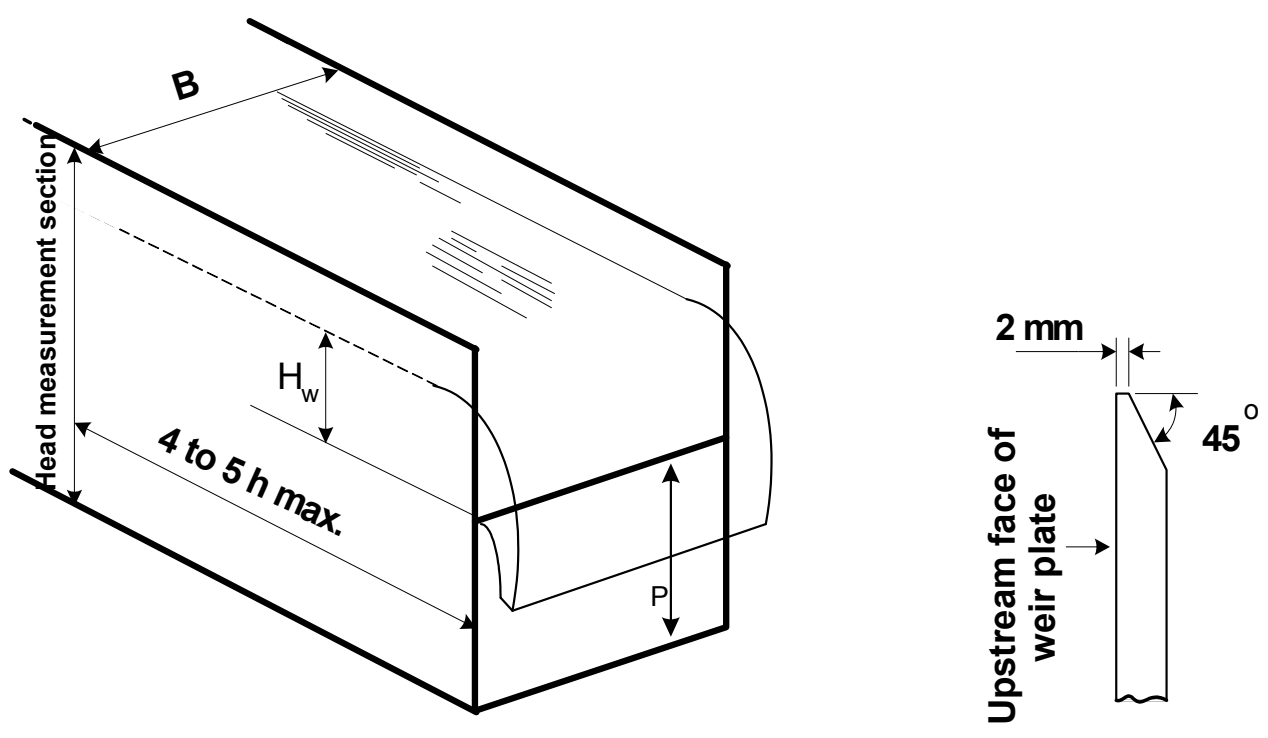

Fig. (5):- Uncontrolled rectangular sharp crested weir.

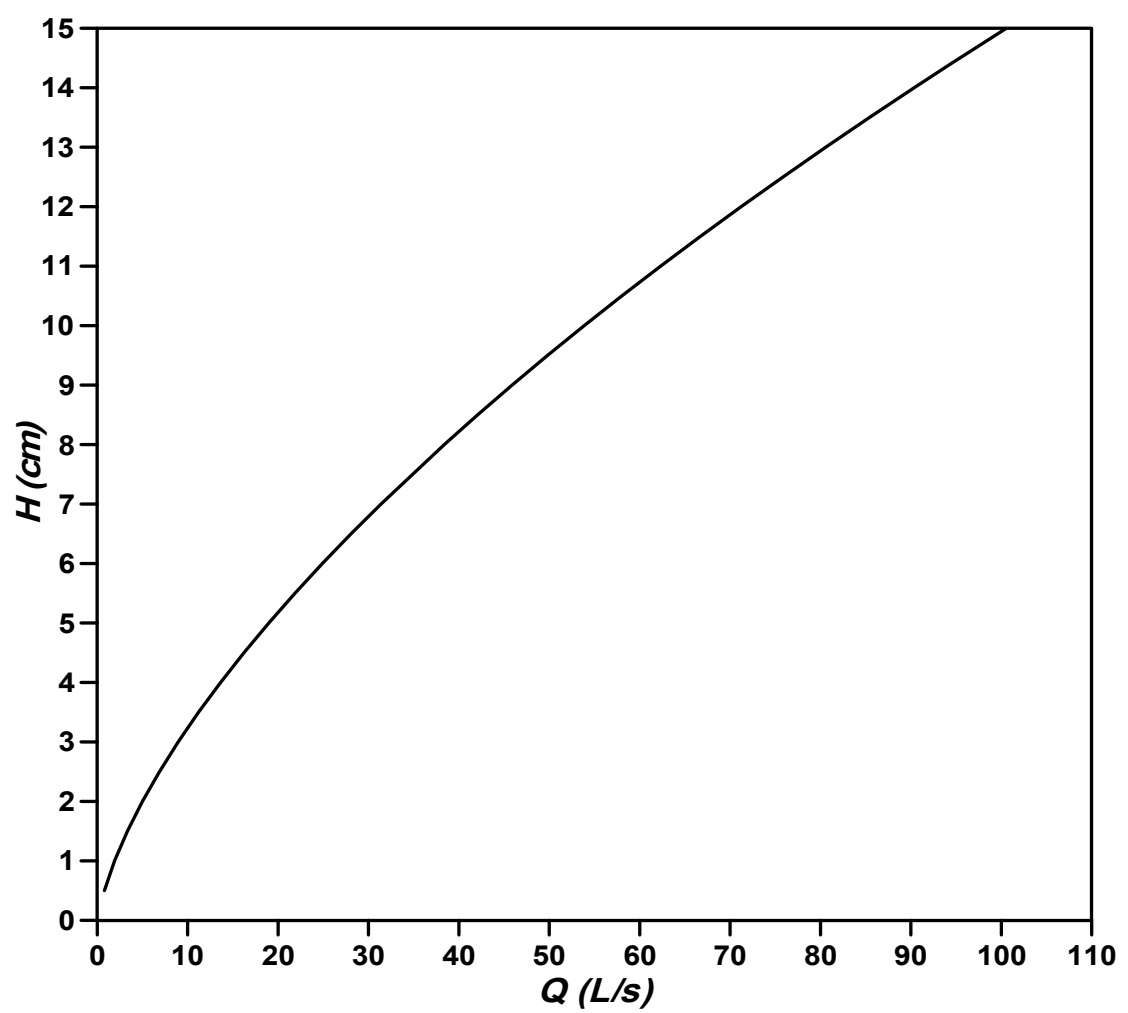

Fig. (6):- Uncontrolled Rectangular sharp crested weir Rating Curve. 


\section{PRESSURE DISTRIBUTION ALONG THE EMERGENCY} SPILLWAY SURFACE

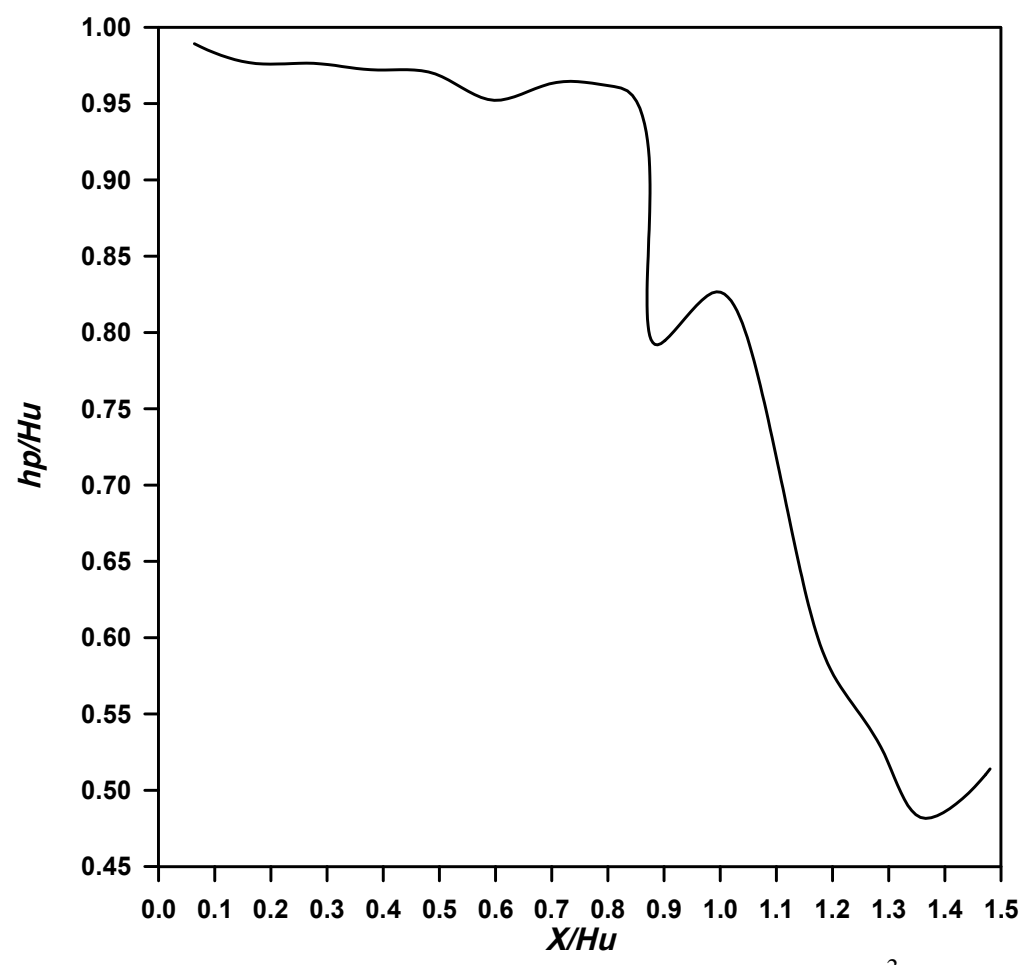

Fig. (7):- For $Q_{m}=2.708 \mathrm{~L} / \mathrm{s}\left(Q_{p}=765.93 \mathrm{~m}^{3} / \mathrm{s}\right)$.

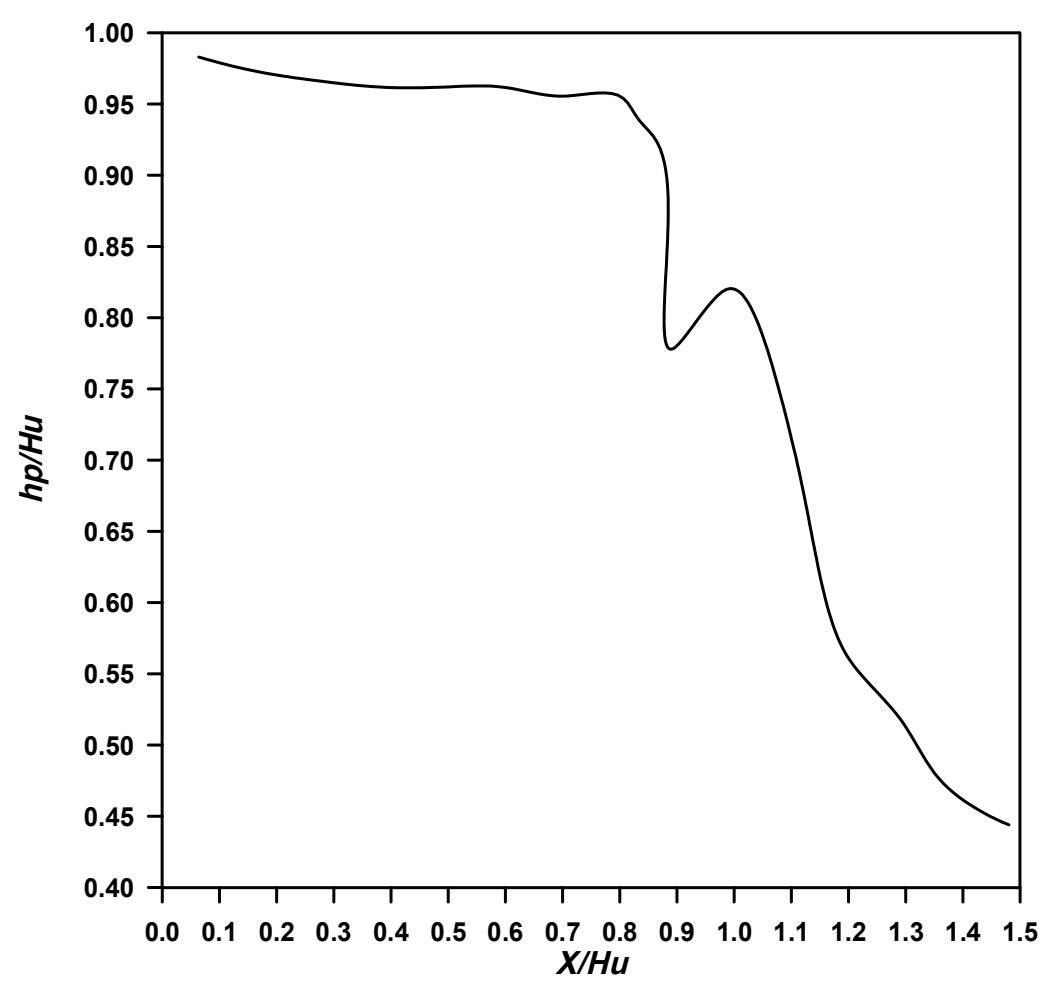

Fig. (8):- For $\mathrm{Q}_{\mathrm{m}}=3.23 \mathrm{~L} / \mathrm{s}\left(\mathrm{Q}_{\mathrm{p}}=913058 \mathrm{~m}^{3} / \mathrm{s}\right)$. 


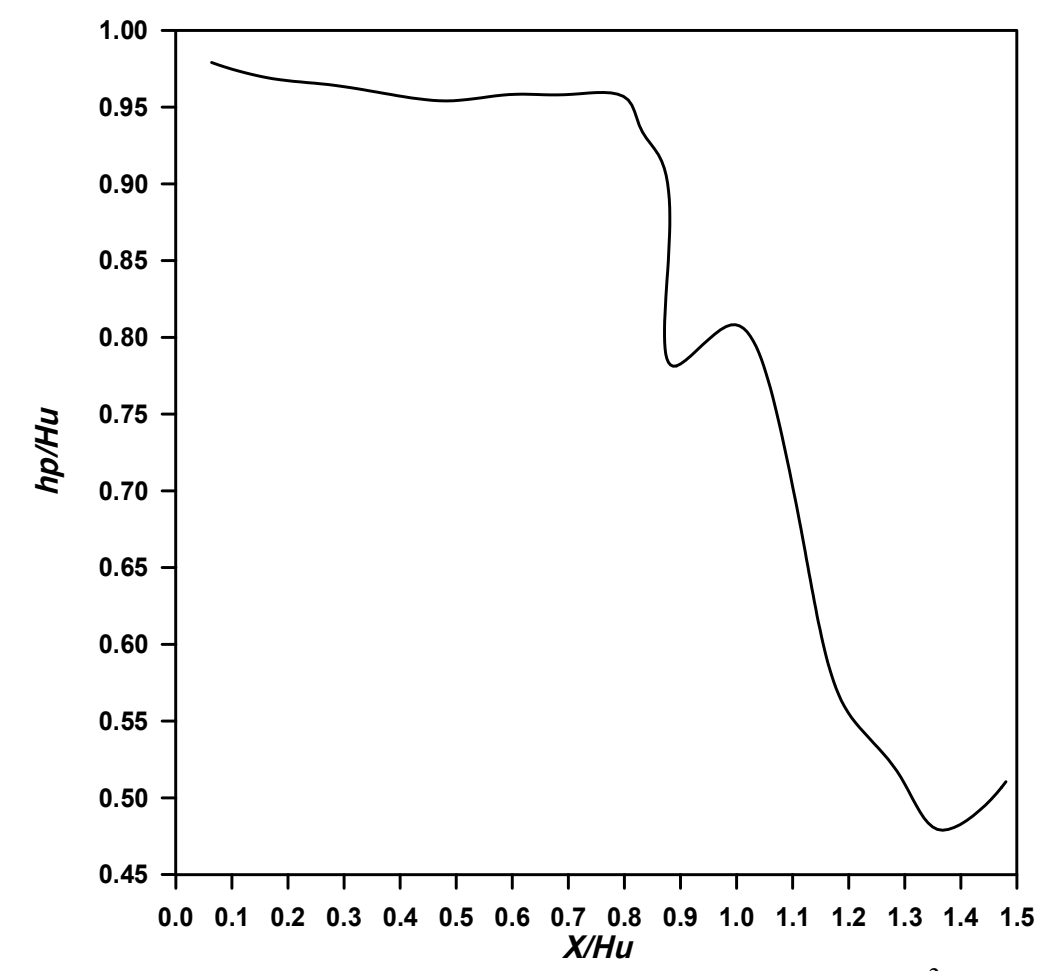

Fig.(9):- For $Q_{m}=3.941 \mathrm{~L} / \mathrm{s}\left(Q_{p}=987.4 \mathrm{~m}^{3} / \mathrm{s}\right)$.

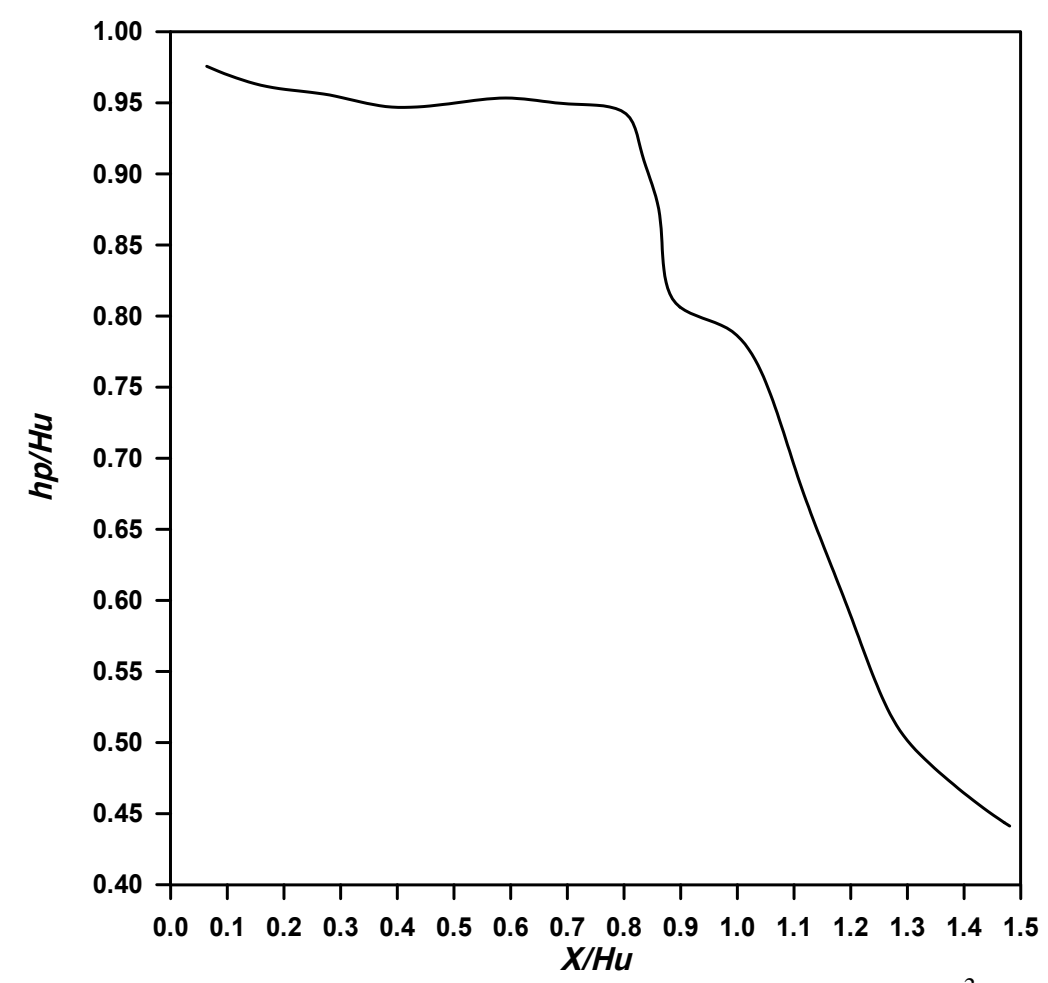

Fig.(10):- For $\mathrm{Q}_{\mathrm{m}}=4.419 \mathrm{~L} / \mathrm{s}\left(\mathrm{Q}_{\mathrm{p}}=1170.96 \mathrm{~m}^{3} / \mathrm{s}\right)$ 


\section{PIEZOMETER READING ALONG THE SPILLWAY SURFACE}

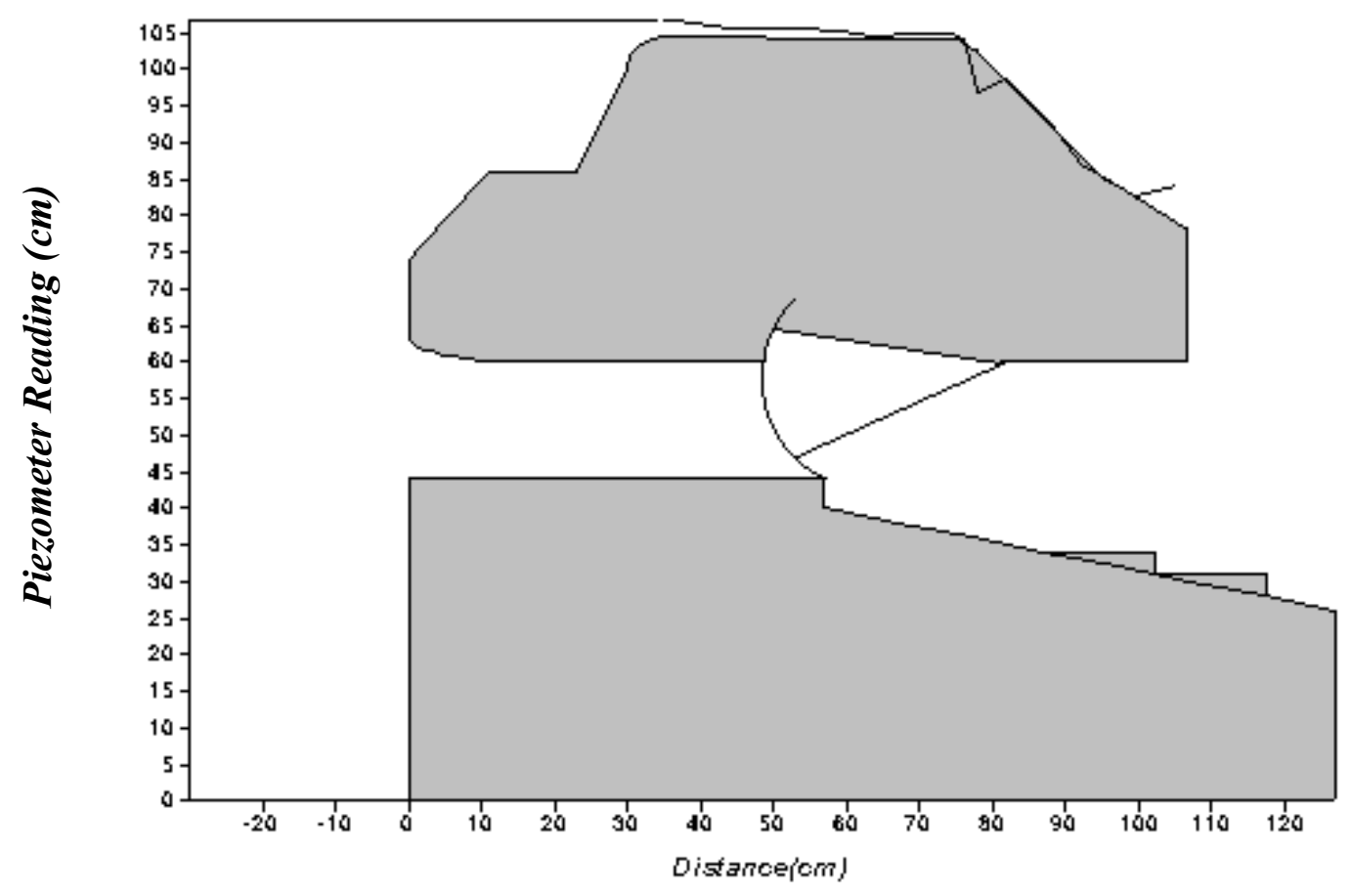

Fig.(11): For $\mathrm{Q}_{\mathrm{m}}=2.708 \mathrm{~L} / \mathrm{s}\left(\mathrm{Q}_{\mathrm{p}}=765.93 \mathrm{~m}^{3} / \mathrm{s}\right.$.

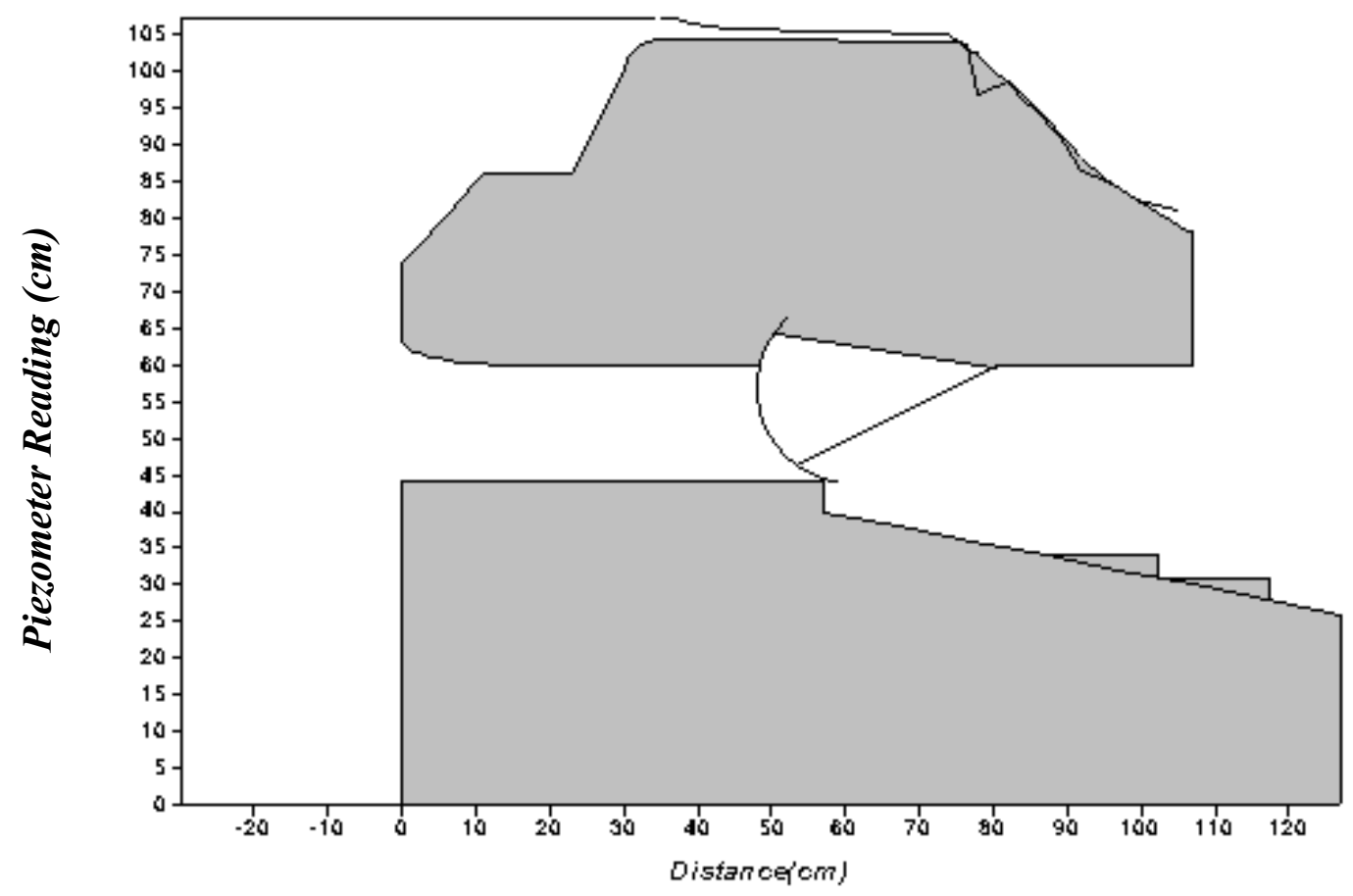

Fig.(12):- For $\mathrm{Q}_{\mathrm{m}}=3.23 \mathrm{~L} / \mathrm{s}\left(\mathrm{Q}_{\mathrm{p}}=913.58 \mathrm{~m}^{3} / \mathrm{s}\right.$. 


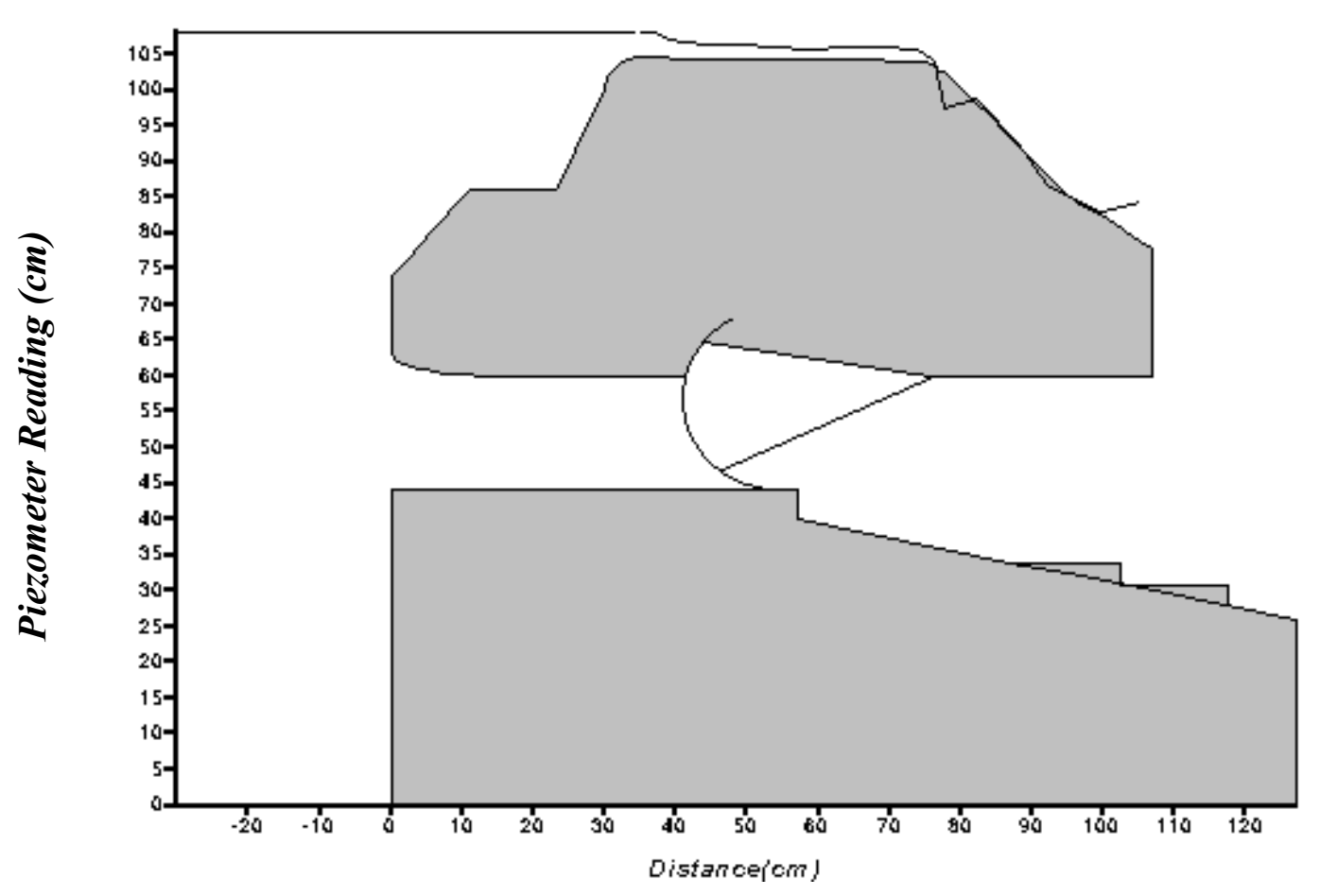

Fig.(13):- For $\mathrm{Q}_{\mathrm{m}}=3.491 \mathrm{~L} / \mathrm{s}\left(\mathrm{Q}_{\mathrm{p}}=987.4 \mathrm{~m}^{3} / \mathrm{s}\right.$.

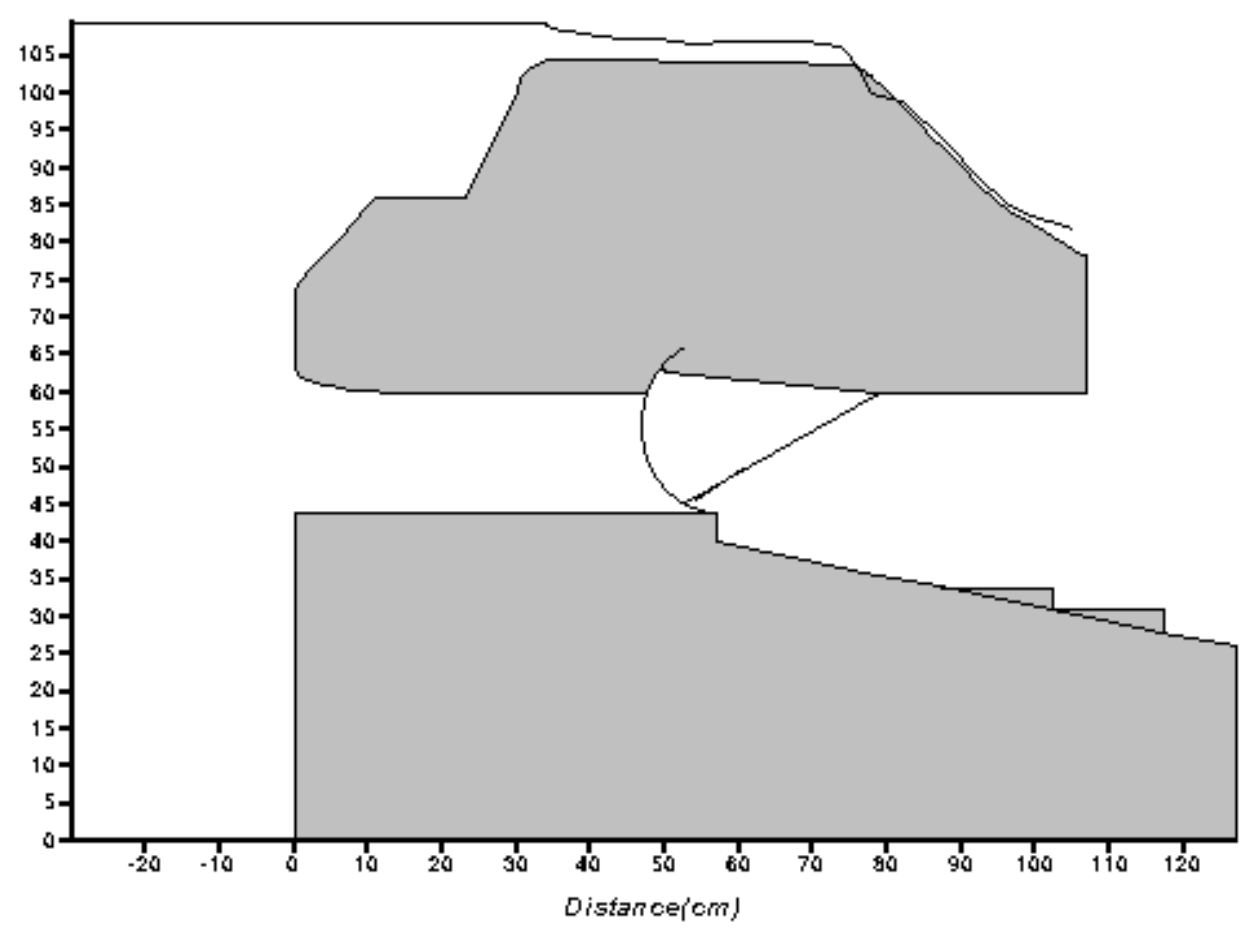

Fig.(14):- For $\mathrm{Q}_{\mathrm{m}}=4.419 \mathrm{~L} / \mathrm{s}\left(\mathrm{Q}_{\mathrm{p}}=1250 \mathrm{~m}^{3} / \mathrm{s}\right)$. 


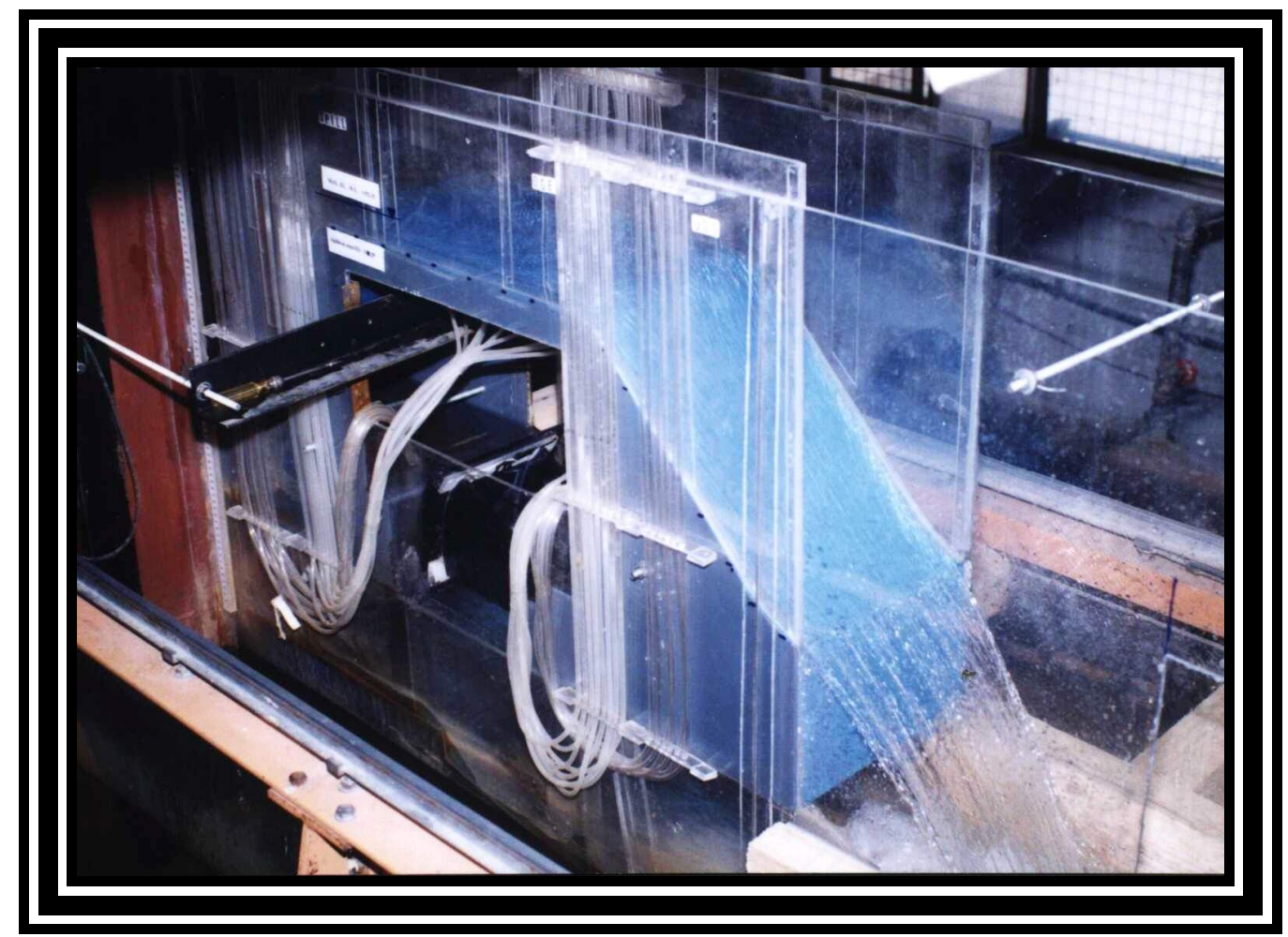

Plate (1):-The Flow over Emergency Spillway.

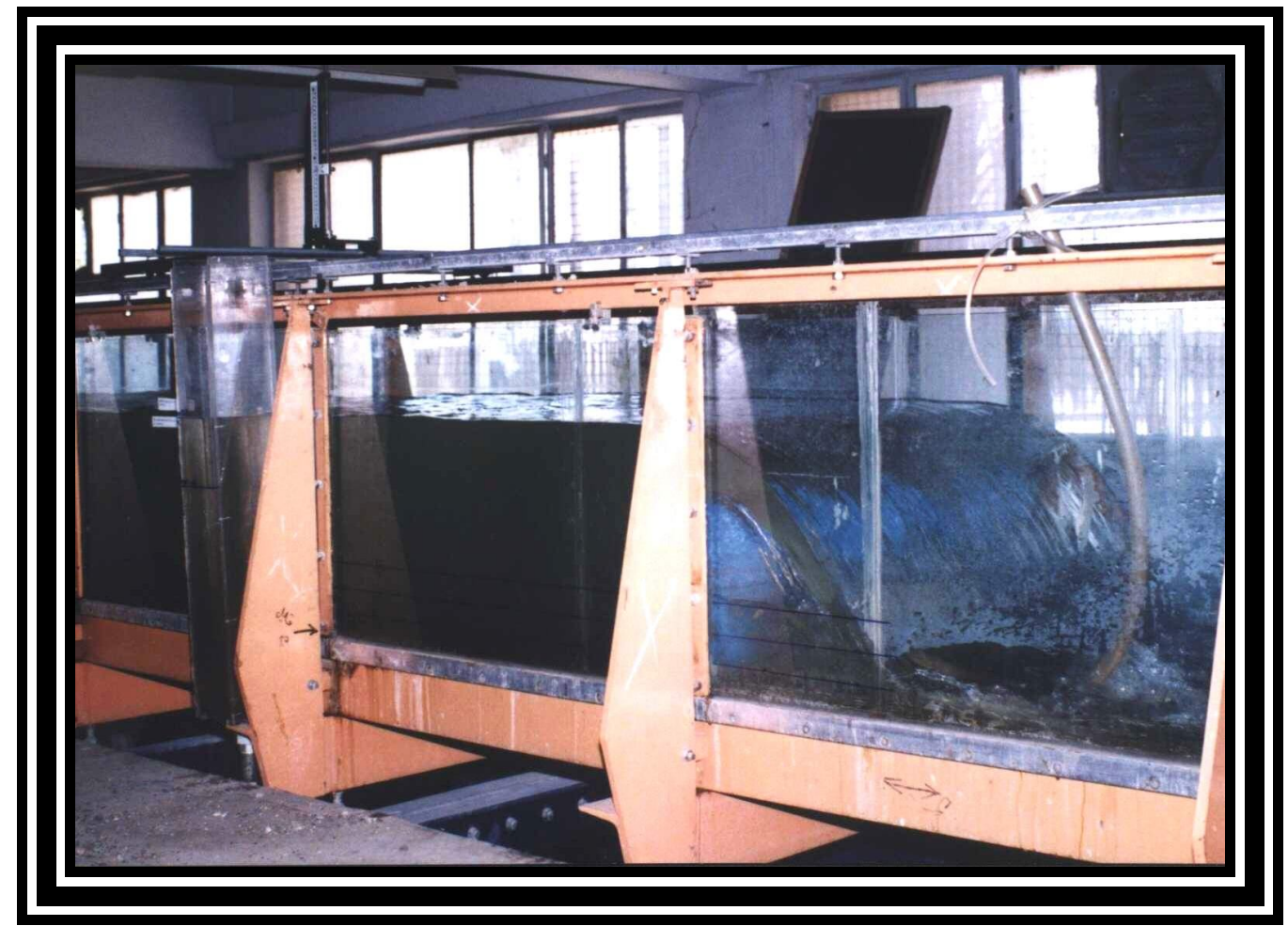

Plate (2):-Uncontrolled Rectangular Weir and Well Gauge. 
الفحص ألمختبري لتوزيع الضغوط على طول المسيل المائي لسد مكحول

\author{
مهند محمد عباس \\ مدرس مساعد \\ كلية الهندسة - جامعة ديالى مدرعاعل ملئ
}

الخلاصة

في هذا البحث تم قياس نوزيع الضغوط مختبريا وعلى طول سطح المسيل المائيلنموذج سد مكحول .اجري العمل

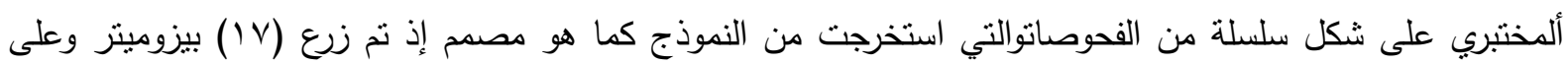

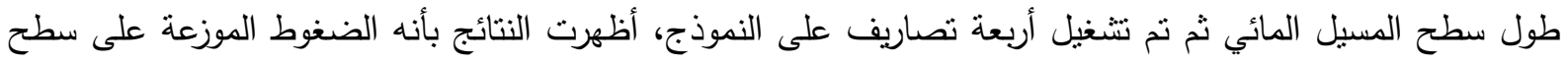
المسيل نقل مع زيادة التصاريف والعكس صحيح أيضا وتبين إنهاللك منطقتين للضغط السالب إحداهما عند منطقة والأخرى عند نهاية السطح المائل لذا من الممكن تقليل ميل السطح الأفقي للمسيل المائي أو تغيير معادلة لتلافي مشاكل التكهف بالرغم من إن القيمنين لم تتحدر لهذا المستوى. (Ogee) 